\title{
The Forests of Naissaare Island in 1297-1698 in relation to the development of the City of Tallinn, Estonia
}

\author{
Heldur Sander ${ }^{1}$, and Toivo Meikar ${ }^{2}$
}

Sander, H., Meikar, T. 2021. The Forests of Naissaare Island in 1297-1698 in relation to the development of the City of Tallinn, Estonia. - Forestry Studies | Metsanduslikud Uurimused 74, 10-25, ISSN 1406-9954. Journal homepage: http:/ / mi.emu.ee/ forestry.studies

\begin{abstract}
The article explores the development of the North Estonian city of Tallinn and the history of the forests on Naissaar, the greatest of the four offshore islands, in the 13th-17th century. In 1219, the northern part of Estonia was conquered by King of Denmark Waldemar II, who built a new stone citadel on the site of the former Estonian stronghold on the hill of Toompea. Under the sovereign rule of the King of Denmark, North Estonia became the Duchy of Estonia. Subsequently, the citadel developed into the settlement of Toompea, the seat of the governor and state authority, and the surrounding areas into the settlement of Tallinn. In 1248, Tallinn gained Lübeck city rights. King of Denmark Erik VI Menved's law of 1297 granted the city of Tallinn and Toompea, i.e., the state, joint use of the insular forests. The law came to be interpreted as the beginning of nature conservation in Estonia, as it was the first law regulating forest use and users. Naissaare forest also served as a landmark for sea vessels. As the state did not interfere with the city's affairs, the latter saw itself as the sole owner of Naissaare Island. Over the next four centuries, Tallinn exploited the Naissaare forests for various purposes. The city managed the forests with relative economy, but not without conflicts, as the provincial government also contended for the use of Naissaare. In 1689, the state asserted its rule over the islands by reduction. The city of Tallinn was forced to terminate the use of Naissaare forests, with the right of forest use reserved to the state.
\end{abstract}

Key words: history, medieval forest, law of King, Naissaar, urban forest.

Authors' addresses: ${ }^{1}$ Retired scientist, Mahtra 9-121, 13811 Tallinn, Estonia; ${ }^{2}$ Retired scientist, Vanasilla 17, 76401 Saue, Laagri, Estonia; *e-mail: heldsander@gmail.com

\section{Introduction}

In European forestry literature, medieval forests have captured relatively much attention. Several acts and deeds regulating forest utilization are known from the Middle Ages. A comprehensive constitutional act from England "Magna Charta Libertatum" from the year 1215, which paid rather great attention to the utilization of forests may be mentioned here
(Hart, 1966). The monographs written by Konijnendijk $(1997,1999)$ are also an outstanding initiative. In his work several aspects related to the history of urban forestry from the Middle Ages until the present time are discussed in a more general way than in the works of other authors. The works of other authors (Brandl, 1973; Gomercic et al., 1997; Profous \& Rowntree, 1993; Roudna \& Urban, 1998) are of great importance here. 
The Middle Ages were characterized by the existence of different laws which regulated forest use in one way or another. Various ownership relations and complicated political relations interacted here. Kings and their feudatory, as well as churches, monasteries and towns who were using the same privileges placed a lot of pressure on forests. We have to take into account that in the Middle Ages a lot of pressure was put on urban forests, especially in regions where towns were growing rapidly. Urban forests were mostly used as a raw material resource (a lot of wood was used for building, port construction and for other urban purposes) because wood was in many aspects a strategic raw material at that time. Since the area of forests belonging to a town was often very small, towns started to purchase and rent forest land.

The present work focuses on a problem of European forests related to coastal and island forests. In the history of European forestry rather much attention has been dedicated to islands and their forests. Islands have always been in the centre of conflicting interests due to their strategic position and forests growing on them, and all this has left an impression on their history.

The article gives a detailed description of the development of forests on islands located in the vicinity of Tallinn (Estonia) in the time period from the 13 th to the 17 th century. Special attention is paid to Naissaar, the largest island near Tallinn.

After subjugation of Estonia by foreign conquerors an administrative system started to develop and problems related to the ownership and use of forests on islands near Tallinn arose. Erik VI Menved, King of Denmark, issued a law in 1297 by which restrictions were imposed on the use of islands. The islands remained in the joint usage of the state power - Toompea stronghold and the down-town of Tallinn. Since the state power did not interfere with the activities of the town of Tallinn at that time, the islands were managed for 400 years by the town only and the town con- sidered itself to be their sole manager.

Among the laws of medieval Europe regulating forest use, development of a prerogative of forest use for only one town was not unique but it was the first such case in Estonia.

The code of feudal customs "Saxon mirror" from the end of the 11th century embraced also Estonia and Livonia (Daniel, 1927; Vilberg, 1932). This code was in force until 1337 when "Legal mirror of Livonia" was validated. Acts regulating and restricting timber cutting were valid also in the adjacent areas of Estonia. The agreement concerning boundaries Riga land tenure (Latvia) of Bishop Wilhelm of Modena and the monastery of Dünamünde from the 17th of March 1226 banned strangers from cutting trees, especially oaks, on the territory of the monastery (LUB=Bunge, 1853: No. LXXX). Understandings of that time touched upon the forest utilization in Estonia where the cutting right was not quite free. The cutting right had to be confirmed with special laws. So, the Bishop of WestSaare allowed in 1256 the merchants to cut in coastal forest trees needed for repairing their ships. The new bishop confirmed this predicable old right of the merchants again in 1262 (LUB=Bunge, 1853: No. CCLXXXIX, CCCLXVIII). In 1274, the Bishop of Tartu (Estonia) also allowed the same in forests near the lakes and rivers of his possessions (LUB =Bunge, 1853: No. CDXXXIX). When the Archbishop of Livonia, Estonia, Prussia and Riga confirmed the privileges previously given to the merchants, a significant stipulation was added that the approval of the landowner was needed for cutting timber for the new ships (LUB=Bunge, 1853: No. CDXL). The privileges given to foreign merchants on the coast - to graze horses on the common, to cut timber in the forests of islands and seaside for repairing ships and heating - were fixed also in the common deed of the Bishops of Riga and Saaremaa (West-Estonia) and the master of the Livonian order from the year 1277 for the territory of the order. These prescripts were as 
custom valid also in northern Estonia and in the territory of Tallinn during the age of the Danish rule (LUB=Bunge, 1853: No. CDLIII; Kivi, 1937; Viidas, 1992).

In connection with the development of Tallinn, the permitted timber cutting on islands near shipping lanes began to restrict the interests of the town and the castle. The King of Denmark (1286-1319) Erich (Erik) VI Menved stood up for his vassals' interests regulating the timber cutting on the above-mentioned islands with his act from the 17th of June, 1297. The largest and richest in forests of these islands - Naissaar with the area of $18.6 \mathrm{~km}^{2}$, about $9 \mathrm{~km}$ long and about $4 \mathrm{~km}$ wide, and with the highest point of $27 \mathrm{~m}$ above sea level, was most influenced by this act. The island situated in the mouth of Tallinn Bay, at ca $8 \mathrm{~km}$ from the capital of Estonia. The island is covered with forests. Only a narrow coastal belt is open and left under the direct influence of waves (Punning et al., 1998). The island was well known to the seamen in the early Middle Ages already, and Arabian coins from the 7th to 10th century have been found here (Gustavson, 1992).

This approach is linked more or less to our previous research: Sander (1997), Sander \& Meikar (1997), Meikar \& Sander (1999), Sander \& Meikar (2020).

\section{History of Tallinn}

In the summer of 1218 the King of Denmark (1202-1241) Valdemar II The Winner (Sejr) assented to the request of Bishop Albert von Buxhovden and the master of the Order Volquin and agreed to arrange an expedition to Estonia in 1219. The Pope Honorius III gave his blessing to Valdemar II with his bull from the 9th of October 1219, releasing to the King of Denmark all the Estonian areas that he would conquer in the future (Pullat, 1976). Henrik the Chronicler described the arrival of the King of Danish Valdemar II: "They all landed in Revala county with their army and established themselves in Lyndanise that had been the Revalians' stronghold earlier" (Henricus et al., 1982) The joint arrival of the King of Denmark, the Archbishop of Lund, the Prince of Slavomans of Rügen Vitslav, the Bishops of Schleswig and Roskilde has been considered an expedition in most cases, but also sometimes a diplomatic mission. The written history of Tallinn, but not the actual history of Tallinn began since then. The latter has been connected by the historians with the existence of an Estonian stronghold.

From 1219 to 1226 was the first Danish era. Valdemar II had the old stronghold pulled down and erected the wooden Taanilinnus (Danish castle). Estonians' repeated attempts to reconquer the stronghold were unsuccessful. From 1226 to 1227 was the era of the papal buffer state. During the quarrels of Germans and Danes about the North of Estonia, the Papal legate Wilhelm Modena tried to establish a Pontificial State between their possessions. The attempt was unsuccessful. From 1227 to 1238 was the first Order era. The Order of the Knights of the Sword based in Riga (Latvia) seized Tallinn in 1227. In 1230, 200 German merchants were called to Tallinn from Visby by the Order and after that the oldest town settlement in Tallinn began to develop in the neighbourhood of Niguliste Church (Pullat, 1976; Zobel, 1994).

From 1238 to 1346 was the second Danish era. According to the Stensby treaty between Wakdemar II and the meanwhile established Livonian Order, Tallinn remained a possession of Denmark. In 1271, Tallinn became the capital of the dukedom of Estonia.

The settlement nucleus became divided into castle (castrum) Toompea and downtown (suburbium). The castles were united by an outer defence zone. Land rights and chivalric privileges were valid on Toompea; from 1248 Lübeck city rights were specified in the downtown. A downtown of merchants and craftsmen together with the magistracy (magistratus) devel- 
oped. The land belonging to the town (patrimonium) was determined in 1265 , when the borders of the town were marked. The area of the lands amounted to 8,230 hectares (Zobel, 1994).

During the years 1227-1238 Tallinn received the same rights as Riga. It is known that since 1227 Tallinn obtained a variant of the town bylaws of Riga (Peep, 1995) and later probably the town bylaws of Hamburg. The latter was rescinded after the re-establishment of the Danish rule in Estonia and Tallinn was given the town bylaws of Lübeck by King Erik IV in 1248 (Kala, 1998). Supposition has been made that King Valdemar II had given to Tallinn the town bylaws of Lübeck already between the years 1219 and 1227 because Lübeck belonged to the King of Denmark during the period 1201-1225 (Riis, 1985). The giving of the town bylaws of Lübeck to the citizens of Tallinn was affirmed by King Cristoffer I on the 16th of August 1255 (DRB= Blatt \& Christensen, 1942: No. 164).

In approximately 1250, Tallinn entered the German trading cities' union, and in about 1280, the Hanseatic League (Zobel, 1994). In 1265 Tallinn was freed from the guardianship of the royal bailiff and the town council elected from among merchants became the power over the downtown.

The King of Denmark Erik V Klipping affirmed on 10/08/1265 in Ringsted the borders of the pastures released to the citizens of Tallinn by Valdemar II, took them under his protection and forbade to restrict or to use them in some other way, threatening with losing the royal favour.

During the period of 1259-1282 the vigorous mother of Erik V Klipping, i.e., the Queen Margarethe of Sambor took an interest in Tallinn and Estonia. No later than in the spring of 1266 she received from the king tenure of Estonia as a lifelong feud. She had in this region the same privileges as the king had and she used in documents concerning Estonia the title "domina Estoniae" until her death in 1282. She had a strong influence on the ruling of the dukedom, in the year of her death she enforced in Tallinn the town bylaws of Lübeck again. The king also named himself as "dominus Estoniae", but since 1269 already as "dux Estoniae" (Pullat, 1976; Hørby, 1993).

The queen dowager Margarethe formed with her edict from the 13th August of 1265 in Roskilde a special commission which was obliged to look over and to mark the boundaries of the territory of Tallinn given to the town by Valdemar II and to determine the conditions for the use of the territory in order not to be unjust to the town. (LUB=Bunge, 1853: No. CCCLXXXIX; DRB= Blatt \& Christensen, 1942: No. 492; Kivi, 1937; Zobel, 1991).

It is not known which were the primary boundaries of the town land tenure determining that islands bordering the routes to Tallinn Naissaar, Aegna and Paljassaar belonged to the land tenure of the town, but the first document on this subject is the testimonial of the abbess of the nunnery of St. Michael in Tallinn from the 6th of February, 1348. The abbess certified that the nunnery had no rights on the abovementioned islands belonging to the town (Kivi, 1937). The nunnery lost the support to the king in consequence of the selling of northern Estonia and in 1348 also had to give up the right of use of these islands on behalf of Tallinn (LUB=Bunge, 1855: No. DCCCLXXXVI). It becomes also evident that the nunnery of St. Michael of Tallinn, founded in 1249 by the Cistercians (was rather impressive and was patronized by the Danish government) had also the right to use the abovementioned islands belonging to the town land tenure (Kivi, 1937). Johansen (1951) supposes that the Cistercians inherited this special right with the patronage over St. Olaf's Church enforced in 1267 (LUB=Bunge, 1853: No. CDIV). It is also known that the merchants of Gotland and their St. Olaf's Church had received from the Estonians the right to use the seashore and forest as well as to graze their horses on the islands near Tallinn already 
before the conquering of the territory of Estonia (LUB=Bunge, 1853: No. CDIV; Johansen, 1951).

A church of Scandinavian merchants had probably been situated on the territory of St. Olaf's Church (first mentioned in 1267) already in the 12th century. So, the right to use the islands was surrendered already before the conquering. It is mentioned that the arrival of the oversea merchants on the coast of Estonia presupposed from the very beginning agreements with local inhabitants which formed into local shore rights in the course of time (Viidas, 1992).

Various privileges and rights including proprietary rights to the forests, fields and meadows within the town territory of Tallinn were guaranteed to the canons of Tallinn by the law given by Erik Menved on July 29th, 1289. All the area of the town territory was in joint usage for grazing, haymaking and woodcutting (LUB=Bunge, 1853: No. DXXVIII). First of all the town and the town citizens could use it, as well as some vassals of Toompea (LUB=Bunge, 1853: No. DLXVI, DCCXCII), the canons (LUB=Bunge, 1853: No. CDLXXXIII), the cloisters of Michaelis and Katharinen (LUB=Bunge, 1853: No. CCCLXX, CCCLXXXII, CDIII, DLVIII, DCXXV) and the hospital of St. Johannis (Kivi, 1959). The usage of forest had been determined by the town council so that nobody could go fell trees with more than one horse and woodcutting was allowed only for one's own purpose, for instance it was mentioned in the case of cloisters. So the principle taken from the old Saxon right was in force that every household was allowed to cut trees in the common forest only for its own purpose and as much as it could with its own workmen (Daniel, 1927; Tiismann, 1931).

Tallinn had become a capital of a feudal region consisting of the ancient Rävala area and part of Harju and Viru area under the hegemony of the King of Denmark. This province received the name of the Duchy of Estonia and the King of Denmark the title of the Duke of Estonia in 1271. The royal power on the spot was rather nominal both in administrative and judicial aspects because of the long distance from the capital of the state and the primitiveness of traffic conditions. However, lots of acts, assurances of privileges and other ordinances as well as documents about various subjects have survived of Denmark or their representatives who ruled Estonia in the 13th and 14th centuries. The King of Denmark gave general instructions but sometimes sent also specialists of the field of broadening, building and fortification of the town (Pullat, 1976). So, Tallinn had turned into a town heart, consistent with the essential surrounding area town territory or hereditary land (Zobel, 1991) and the devilment of the town were assured.

From 1346 to 1561 was the second Order era. In 1346 and 1347, Tallinn and Northern Estonia were bought successively by the Teutonic Order and the Livonian Order. This was a period of economic flourishing for Tallinn. Most of Tallinn's stone buildings, including the town wall and its towers, date from that time.

From 1561 to 1710 was the Swedish era. In the long Livonian War (1558-1583) between Sweden, Poland, Denmark, Russia, the Teutonic Order and some minor powers, Tallinn was sieged on three occasions. The town was not conquered but there was a great deal of damage.

From 1710 to 1918 was the Russian era. The Northern War between Russia and Sweden (1700-1710) ravaged the whole country. The war was accompanied by plague. When Tallinn surrendered after a short siege in 1710 , only $1 / 5$ of the inhabitants were alive. Tallinn became a gubernia (province) centre in The Russian Empire (Zobel, 1994).

From 1918 to 1940 was in Estonia the first Estonian era, from 1940 to 1991 the Soviet era and since 1991 the second Estonian era. 


\section{The law of the King of Denmark Erik Menved from 1297 for the forest of Estonia}

On the 17th of June of the mentioned year the King of Denmark Erik Menved VI signed the following document (LUB=Bunge,1853: No. DLXVI): Erik, the King of Danes and subordinated nations by God's grace, the Duke of Estonia, wishes everyone reading the present document, salvation by the Lord forever. We ban severely by the grace befallen to us everybody and in any conditions to cut trees or to burn charcoal on our islands Nargheten /Naissaar/, Wulff /Aegna/, Blocekarl and Rughekarl / now the peninsula Paljassaare/, except for our castle and town of Tallinn, as the custom has been from the ancient times, if our condemnation and royal punishment are wished to be avoided. As a testimony of this time we let to add here our stamp, given in Roskilde, anno Domini 1297, on the day of the blessed Bocolphus, the alet and witness, in presence of us and honorable father Johannes (Jens), the bishop of Roskilde and the witnesses, Mr. Nicolaus (Niels), called Biker, our castellan Achone Jonesson (Aage Jonsen), our former castellan David Thorstinson (Thorstenson) and Otto von Rosen.

The documented history of the forest protection in Estonia began with the law from the 17th of June, 1297. It is also mentioned that due to this juridical act the Tallinn Bay and the islands became an inseparable part of the town territory of Tallinn (Viidas, 1992; Sander \& Meikar, 2000) and in the act these islands were first mentioned in the legislation of the Danish Kings. Why was this law necessary? Evidently, especially on Naissaar, several interests contradicted on the islands near Tallinn. Already the law itself and the persons attending the enforcing of the law refer to this. As we see, the king had to point out in his law "as the custom has been from the ancient times". Probably he referred to something earlier than to the prescripts of his forefather Valdemar II. It is mentioned that this assertion refers to the acts and laws that were in force with the Estonians earlier, before the conquest (Vilberg, 1932). The merchants of Gotland and their Church of St. Olaf had received from the Estonians several rights of using of the seacoast and forest and grazing their horses on the islands near Tallinn (Johansen, 1951).

When we have a look at the persons attending the enforcing of the law by the king, we can see that Otto von Rosen was the only one from overseas. So, no ruler from Tallinn was present and maybe it was not necessary, either because the principal decision had been made already earlier. Who was the aforementioned person, and what were his relations to Tallinn? It has been considered possible that Otto von Rosen was a Dane and he was a vassal both of the Archbishop of Riga and of Denmark. He belonged several times to the close circle of the king when the relations between Denmark and Estonia were discussed (Von Transehe-Roseneck, 1935).

Denmark supported Riga in every respect. Riga belonged to the league of cities of northern Germany (later Hanse) and the Teutonic Order tried to subject the town. The civil war that began in 1297 finished with the success of the Teutonic Order on 29/06/1298. Stiftsfogt O. v. Rosen, the army leader of the archbishop, was also killed then (Von Transehe-Roseneck, 1935). It has been mentioned that the Danish Duchy of Estonia owed its establishment and preservation to the protection of the pope. The pope could often keep away competitive interests of the West. He had for several times given to the king or bishops of Denmark power of attorney on somewhat broader territory than their actual influential circles (Hørby, 1993). The fore-mentioned date was important to Tallinn also from another point of view. On the same day, the 17th of June, the king with the same company enforced also laws liberating citizens of Tallinn from the shore 
rights and the law dealing with corn export (DRB= Blatt \& Christensen, 1942: No. 258). If we consider $\mathrm{O}$. $\mathrm{v}$. Rosen a representative of the pope and the Bishop of Riga, his presence in Roskilde is somewhat understandable. One must also take into account the matter that King Erik Menved had to cancel the privileges given to the foreign merchants on shore to graze their horses on common lands, to cut trees in the forests of the islands and the coast for heating and repairing their ships.

One of the reasons of the order from 1297 may also be the shortage of forests on the town territory of Tallinn. Only the Kopli Peninsula with its oak forest was relatively rich. Groves of deciduous trees occurred here and there on the plain under Mustamäe Hill. Few conifers grew within the continental part of the town territory (Zobel, 1991). It was due on the one hand to the natural conditions (clint, alvars, sandy regions, overly moist regions, etc.), and on the other hand to the constantly growing necessity of wood.

The forests in the vicinity had decreased due to the unregulated cutting, but the need for timber had increased especially in connection with the development of Tallinn. Timber was an important building material, it was needed for the fencing of pastures and gardens, filling of roads, burning of charcoal and lime, distilling of tar, etc. In such conditions the most important forest reserve of Tallinn was on Naissaar, less on Aegna. A considerable economical load could influence the islands near Tallinn already, including ships visiting Tallinn or passing by. The navigation became, of course, especially frequent after the establishment of the town. The ships were also often harbored at Naissaar during storms, and timber was again needed for repairing.

Taking into account privileges given to the merchants, the order of the King of Denmark from 1297 must be considered an exception from a generally valid tradition. Cutting of timber on the islands by the shipping lane restricted the interests of the favourite of the king, the town and castle of Tallinn. At the same time, no cutting limitations are known for the town and the castle. This was based on the custom, later on the orders of the Town Council (Meikar, 1998). Probably also the need for forest was the reason for pretending to the territories on Viimsi Peninsula (east of Tallinn) by the Council of the City of Tallinn based on an old custom. That was also the reason for several conflicts in 1397 and 1471. Several villages in the neighbourhood also belonged to the castle of Tallinn, so obviously Tallinn could use common forests, as well (Viidas, 1992).

There is no reason for talking about the forest on Naissaar Island as a protected forest, at least not at that time, because cutting was forbidden only in the interests of the owners. It is quite another problem that the city of Tallinn later interpreted the law in this way.

So, the above-mentioned document was connected with the restriction of the circle of the forest users. The forests of Naissaar could be used only by the city of Tallinn. But the law from 1297 was very important for the city of Tallinn and, of course, also for the further development of the forests of the islands.

\section{The forest of Naissaar as an important seamark}

Several authors have mentioned islands near Tallinn (especially Naissaar, but also Aegna) and the forest on these islands as important sea marks. The first sources about Naissaar originate from the 11th century from a monk Adam of Bremen; he tells about an island called Terra feminarum. Also a land of virgins - Virginium Terra is mentioned in a manuscript "Historia Norvegiae" from the 12th century. A toponym Amazonia has also been used. Naissaar is mentioned as a sea mark in a written instruction from the 12th century "Navigatio ex Daniae per Baltikum ad Estonia" (Navigaton on the Baltic Sea from 
Denmark to Estonia) - under the name Narigeth. The toponym refers to a narrow part of the Gulf of Finland (narrow gate). The toponyms Nargen and Nargö derive from this name (Gustavson, 1992).

According to the manuscript of Adam of Bremen and messages of the Arabian geographer Idrisi, Naissaar is an important place on the shipping line of the Danes (Tiik, 1957). It is mentioned that the most favourable place for crossing the Gulf of Finland is on the Tallinn-Porkala line, more precisely from the northern top of Naissaar to the islet Mäkiluoto. This islet is situated south from Porkkala, 19 sea miles from Naissaar (Tiik, 1957). Tiik (1957) writes: "considering the height of Naissaar and that of the forest growing on it as well as the height of Mäkiluoto, it is obvious that sailing in the right direction by the landmarks, the second island arose over the horizon before the first one had time to disappear". His calculations demonstrate that if the height of the highest point of Naissaar is over $24 \mathrm{~m}$ and that of the spruces growing on it $25 \mathrm{~m}$, it is enough of $5 \mathrm{~m}$ height for the islet Mäkiluoto, to see Naissaar from there.

There is no doubt that Naissaar was known as a daytime sea mark since the ancient times. However, we have no documental evidence to the supposition that also the interests of navigation were taken into account by enforcing the law by Erik VI Menved. The text of the law does not ban the cutting on the highest hill of Naissaar - Kunilamägi and there is no other documental evidence either (Alamaa \& Kivi, 1966). There was no real need for it as we see later. The cutting ban in the interests of navigation was enforced on Naissaar in 1764 under quite new and changed circumstances.

\section{The forests of Naissaar under the city of Tallinn}

Up to the year 1346 Tallinn belonged to Denmark as the capital of the duchy. After the legal act by Erik VI Menved from 1297 and the reconciliation of the arguments with St. Michael's Cistercian nunnery, which, in 1343 and 1368, acknowledged the rights of the town to the islands, Tallinn could consider the forests of the nearby islands as town's property. Although these were the common domain of the castle and the town, the latter became the actual manager of the islands.

Since 1360, reports about contracts between the Town Council and the lumbermen cutting wood on Naissaar and Aegna almost annually appear in the account books of the town. They determined the amount of wood to be cut, its price, the conditions of delivering, etc. These contracts were usually concluded in autumn, in winter the timber was cut and in spring it was transported to the mainland, either floating or in large punts. Winter transportation by ice tracks was rare. The forests of the islands yielded mostly timber, but with the development of brick and lime burning in town, also fuel wood.

The men cutting wood on the islands were called "island people". They worked in groups of 3-6 men and were mostly Estonians. It is known that of the lumbermen who worked on Naissaar in the years 1354-1372 only one was a Swede, the rest were Estonians. The logs were transported to the shore by horses; the town had sent teamsters with the lumbermen's groups (Pullat, 1976; Gustavson, 1992, 1994).

While felling on mainland Tallinn was rather poorly regulated, with a few exceptions (e.g., in Telliskopli), felling on the islands was under the Town Council's strict control. This was reflected in various acts of forest use, and also in attitudes. It has been mentioned that strict order applied in felling, the cutting units were determined beforehand and their borders could not be violated (Gustavson, 1992, 1994). It is also known that in 1409 two foreign seamen were punished for unlicensed felling on the small island of Aegna near Tallinn (Johansen, 1951; Viidas, 1992). So, the onetime decree of the king was quite effective. 
The island forests belonging to the town were under the control of chief foresters (Waltherren) chosen among the aldermen. Concerning the largest of the islands, Naissaar, a forest warden or a forest bailiff (Holzvogt) has been first mentioned in 1552. In 1555, an Estonian named Peter Harrie (Harju Peeter) was nominated for the forest warden who, besides watching over the town's forests, had to keep an eye on the citizens' horses grazing on the island (Johansen, 1951; Johansen \&Mühlen, 1973).

In 1433 the island of Naissaar provided timber for the rebuilding of Tallinn devastated by fire. In the account books of the Town Council it appears that during the period 1433-1442 wood was regularly cut on Aegna for lime burning, but also for renovating the harbor constructions. The logs were floated to town, while the fuel wood was evidently transported in ships or punts. In winter transportation along ice tracks was also possible. It is not known whether the notes concerned the making of the floats, or the transportation, or both (Viidas, 1992). In 1544 and 1546 exceptions were made and peasants from Iru and Väo villages, which were poor in forests, also got the permission for felling on Aegna. But in 1552 it was observed that on Aegna trees were only sufficient for the needs of the Town Council of Tallinn. The citizens had, from now on, to procure their building timber and fuel wood from the more distant island of Naissaar (Johansen, 1951, Johansen \& Mühlen, 1973).

In 1546 three thousand beams were transported from the island. In 1570 it was mentioned that timber had been brought from Naissaare to Tallinn with 200 sledges - such kind of transport was seldom enabled by ice conditions (Kivi, 1975).

At the same time the set of the users was quite wide. Besides the town and its inhabitants, felling permission was given also to several tenants of the town's territories (Kopli, Habersti, Väo) and peasants. From the year 1415 it is known that in Telliskopli (the present-day Kopli peninsula north-west part of Tallinn), belonging to the town's mark since 1365, by the agreement with the Town Council, only 7 fishermen's huts were allowed, with determined measurements; the fishermen could have 7 horses but no cattle (probably on the account of the ban on forest grazing). Neither could they use the local forest, but had the permission to obtain their fuel wood from the islands near Tallinn, which has been repeatedly referred to later. For instance, in 1611 the Town Council signed a lease for 8 years with Hans Dehn for the aforementioned Telliskopli. The tenant had to obtain the necessary fuel wood from Naissaar. Next, it is known that in 1633, Telliskopli was leased to 2 tenants for 30 years. They, too, were allowed only a limited use of the local forest and had to procure their fuel wood from Naissaar and Aegna (Nottbeck, 1884). The town also began to bring the fuel wood for Kopli brickworks from the islands, the first references of it dating from 1632 (Gustavson, 1994). Probably it was done before that already. The brickworks was founded already in 1265 for manufacturing bricks and roof tiles (Nottbeck, 1884; Pullat, 1976) and the felling of fuel wood in Kopli was limited or altogether forbidden. The fuel wood for lime kilns, functioning on Köismäe since the $2^{\text {nd }}$ half of the 14th century already (Pullat, 1976) was also obtained from the islands since the 15th century (Gustavson, 1994).

In 1658, the neighbouring Väo estate, village and the Lükati mill were leased to burgomaster Bernhard Hetling for 20 years, in reward for 3,300 rix-dollars lent to the Town Council at various times. According to the agreement the tenant was to improve lands and repair the buildings. The pledge received also the free cutting right in the forests of Naissaar and Aegna, with the obligation to inform the respective "Waldherr" (member of the Town Council who ruled the forests) beforehand (Alamaa \& Kivi, 1966).

On account of transportation conditions, mostly quality timber was procured on Naissaar, though in the 17th century a 
mention has also been made about clearing away windfall (TCA, F. 230, No. 10). This confirms the economical use of the forests but also proves that notwithstanding the modest felling and weatherproofness, the forest was sporadically brushy. Quite positively it also performed the function of a daytime seamark, although the references of any definite felling limits are missing.

In the 17th century, a sharp conflict developed between the City of Tallinn and the Governor representing the Swedish power, over the use and even the ownership of the forest of Naissaar. It started with the argument about the borders of the town's mark, while the special interest of the State in this island became gradually more evident. The base of this argument was the ambiguous regulation from the year 1297, which determined the common use of the islands by the town and the castle. While it did not cause problems earlier, it meant a conflict with the central power in new circumstances. So, the Governor of Estonia asked for documentary evidence of Naissaar belonging to the town from the Town Council in 1642. In 1643 the state land surveyor D. Reimers tried even to dispute the right of the City of Tallinn to Naissaar. To settle the matter, a special commission was formed, but it was also unable to offer any solution (Alamaa \& Kivi, 1966).

The Governor of Estonia took advantage of the situation and procured 500 beams, 5,000 fence planks and 100 cords of firewood from Naissaar, without informing the town, which later added to the resentment of the town (Gustavson, 1994). Subsequently, the Queen Kristina of Sweden had to interfere. In the royal resolution of November 23rd, 1653 she firmly opposed the trespassing on the forests of the islands, and stood by the town in their protection (Nottbeck, 1884).

Several constructions in the town constantly needed timber, and again and again it was procured on Naissaar. It is known that Kaarli Church in Tallinn was built of wood from Naissaar and Aegna islands in 1670 and at the end of the 16th and the beginning of the 17 th centuries, beams were used in great numbers for the harbour construction. They were brought from the Kolga forest and Naissaar (Pullat, 1976). The administration of the Government also began to take advantage of its rights on the joint property, first of all felling timber for fortifications. Naturally, this aroused protests and counteractions in the Town Council, which tried to regulate the forest use on Naissaar, one way or another. We know that in 1685, a special guard was sent to Naissaar with the task to watch that the felling for the Town Council would not exceed limits. The forest was devastated also by outsiders. In the aforementioned year the Town Council complained to the Governor General of Livonia that the Governor of Estonia allowed lumbermen to the island without consulting the town. Something unexpected appeared - a peasant from Viimsi, caught in the act of felling, presented a permission to cut 100 beams, bearing the signature of the Governor of Estonia. The Town Council sent a protest to the Governor's residence on Toompea, calling attention to the town's right to decide on Naissaar. A sentence in the protest describes the attitude of Tallinn towards Naissaar: "1/4 of the island has been picked out for all sorts of useless clear cutting, which stands beside the town like a sanctum and treasure". The Town Council also emphasized that only exceptional felling was allowed there for the town's fortifications and Toompea, but for the latter, the Town Council was to give special consent on every occasion (Gustavson, 1994).

The period of most extensive felling on Naissaar and Aegna was evidently before the Great Northern War, for the fortifications of Tallinn. The roads from the country and the suburbs through the fortifications' zone into the fortress and the town were blocked with several constructions: first barriers, then drawbridges, and finally wall gates, front gates and inner gates. All the other nearby entrances and accesses as 
well as the slopes of the walls were fortified with palisades. To build these, the forests of Naissaar, Aegna, Hiiumaa and other nearby islands were not sufficient; timber had to be brought in great volumes from Finland as well (Kenkmaa \& Vilbaste, 1965).

A solution unfavourable to Tallinn was reached in 1689 - in connection with the reduction of the estates, nearly all the town's mark including the islands was nationalized to the Swedish state. While the town could use other parts of its possessions, the islands were taken under direct state management (Alamaa \& Kivi, 1966). This meant that the town was denied any economic activities there, including felling. If the tenant of Telliskopli maintained his felling right on the island, it was granted to him by the province administration (TCA F. 230, No. 10).

The oldest known map of Naissaar, dating from the end of the Swedish rule, 1700 , explains also the forest conditions there. The primitive forest divisions and the accessory text explain that most of the island's forests were relatively young pine forests of natural revival, but a regular matured timber forest was missing. Only a few old trees had survived and the fallen trees had not been cleared away. The other part of the island consisted of wetlands, where young spruces and few birches grew (Truus \& Ratas, 1995).

The capitulation of Tallinn to Russia agreement of 1710 promised to restore the former landed property, as unlawfully expropriated, to the town. With the Uusikaupunki peace treaty in 1721 the Town Council got the possibility of directly appealing to the Czar of Russia Peter the Great in connection with the promises made about the marine islands. The commission for restitution which worked in the years of $1725-1728$, restored the islands of Paljassaare, but on April 4, 1728 passed the negative resolution about Naissaar and Aegna, which was ratified by the Senate (Supreme Court) on October 15, 1742 (Nottbeck, 1884; Pullat, 1976). The reason given was the same resolution of joint usage from 1297. On the basis of this island Aegna, for instance, was included to the Viimsi estate of the Governor (Johansen, 1951). Concerning Naissaar, it was observed that the town has not been able to prove its right on the island and, as if in reward, was given the permission to use the forest for the communal needs of the port and the town (TCA F. 195, No. 1). At least the latter promise was never fulfilled, if we do not consider the few proffers from the beginning of the 19th century, of the possibility of clearing the windfall on the island for fuel wood.

\section{Conclusion}

Summing up the historical document, a conclusion can made that the legal act from the 17th of July, 1297 was a partial cutting ban that had to guarantee the free rights of forest use of Tallinn town and castle on the above-mentioned islands. Tallinn needed a backcountry - town territory with fixed borders - for its development. The wooded islands were of interest of the town as a reserve of timber and also as a seamark standing in front of the harbor. The law of 1297 means also the beginning of the regulation of the legislature when the rules resulting from customs were either enacted or nullified. With the law 1297, Estonia joined the European countries where forest use was restricted legally. However, the legislature dealing with forests began in the 13th century, noticeably later than in civilized countries of Europe. So, the cutting ban enforced in 1297 has no special importance, at least in a broader context. Unfortunately, we do not know how often the cutting bans in other European countries have been initiated by the interests of a single town. It is possible that here we have an example of a few (or only) cases in the history of forestry of the Middle Ages.

The arrival of foreign merchants on the coast of Estonia actually presupposed initial agreements with the local people. These agreements developed into the local 
city council law. In the mid-13th century, the post-conquest era, the new landlords specified this law and extended it to Old Livonia as well.

On the other hand, Naissaar has also become famous for forcing a crack in this convention. Obviously, this concerns the law of June 17, 1297, of the Danish King Erik VI Menved. It stipulated that only the city of Tallinn and the fortress of Toompea are entitled to fell trees and char wood on Naissaar and other islands in the Tallinn Bay. Concerning this law, the following points must be emphasized:

1. It was a royal law regulating the use of forest. It restricted the circle of users to the city and the fortress. They, in turn, were sanctioned to determine the scope and method of forest use. Later developments demonstrated that the Council of the City of Tallinn was moderate in claiming the rights. At the same time, it organized keeping the accounts on logging, as well as the forest watch on the island itself. The regulation of forest use in itself was not extraordinary thing in Old Livonia. The law on the forest of the Dünamünde monastery, which in many respects is analogous to that of Naissaar, was issued by Wilhelm, the Bishop of Modena, as early as March 17, 1226.

2. The law does not refer to Naissaar as a special daylight seamark. In addition, it stipulated no logging restrictions that the status might otherwise have entailed. Apparently, there was no need for that, since both the sovereign and, even more so, the port of Tallinn viewed Naissaar as a seamark, which is in an obvious need of preservation. It is remarkable that it was only in 1764 that the state authorities officially started to treat Naissaar as a seamark. The reason was that the island was rapidly losing this function due to the devastating lumberjacking.

3. The law of 1297 and the other previous indirect evidence suggest that
Naissaar and other local offshore islands belonged to the city of Tallinn. Documentarily, however, it cannot be proved until as late as the first half of the 14th century. The reservation of the rights of forest use to the city and the fortress, consequently to the representative of the Toompea-based state authorities, was among the weightiest arguments that later forced the city of Tallinn to waive its proprietary rights to Naissaar and Aegna.

Since the mid-14th century the city of Tallinn could already regard the forests growing on its nearby islands as the municipal property. Although in legal terms the islands were an object of joint use by the city and the fortress, it was the former that became their actual administrator and manager. The fortress had to coordinate its forest use with the city council. At least initially these circumstances presented no problems. Little is known of Naissaar's forest of the day itself. It was referred to as a blend of spruces and pines, with a substantial share of old trees. Due to the transportation difficulties, only good timber was taken out of it. As a result, the forest looked brushy in places. At the latest since the 17th century extensive efforts were made here to clean the forest of windfallen trees. At that time, the traditional selection felling was used, although apparently only in regions appointed by the city council. Forest use was relatively moderate; there are no reports of excessive cuttings of the forest at the time. The more extensive felling evidently started in the late 16th and the early 17th centuries due to the construction of the structures of the port of Tallinn.

After the transfer to the Swedish rule in Tallinn, however, the city started to have problems with the new authorities concerning its offshore islands, since it was unable to convincingly prove its sole rights to them. For instance, the Governor of Estonia ordered the cutting of 500 trees, 100 cords of wood, etc. on Naissaar in 1645 without even seeking a pro forma permission from 
the city council. Although in a similar controversy in 1653 Queen Kristina took the side with the city council and demanded that the devastation of the forest be stopped, the move was out of step with the real run of life. Since the fortification works of Tallinn required a great amount of timber, Naissaar became one of the suppliers of raw material for them. The plan of Naissaar of 1700 provides an idea of the cuttings of the second half of the 17th century. According to it, the majority of the forest on the island was made up of young pine trees that had emerged as a natural aftergrowth. The document made no reference to matured timber forest, although there were a few old trees left there. The forest was full of deadwood. On the swampy areas of the island there grew young spruces, to a smaller extent also birches.

During the 12th and 13th centuries some local laws and agreements restricting the forest cutting were in force in Estonia, mainly in the surroundings of towns and in densely peopled and therefore scantily wooded countryside.

The few preserved references demonstrate that the town's attitude towards its forests, especially on Aegna and Naissaar, was, in a modern sense, thoroughly economical. Selective felling was applied, on modest degree evidently - at least reports of any greater waste of the forest are missing.

The law of 1297 was a diplomatic move by the King of Denmark. On the one hand, his aim was to oust the competing forest users (here: merchants) from the islands near Tallinn, although the move was counterproductive of the king's pursuit to promote trade via Tallinn to Novgorod, as mentioned before, in that it was detrimental to the merchants' interests by restricting their privileges. On the other hand, the king bestowed the privilege to use the forests on the islands near Tallinn on both the state and the town of Tallinn. This verdict lent itself to dual interpretation in legal terms and embodied a seed of future conflict. The state authorities, however, were unwilling to as- sert their rights. Consequently, the privilege was left for Tallinn to enjoy. The town started to treat the islands as its property in the following centuries. Under the management of the town the islands' forests were untouched by the devastating felling. Thus, the forests on Naissaar, the greatest of the four nearby islands, survived throughout the ages. When the state authorities grew more powerful and its institutions changed, however, the town had to surrender the islands four centuries later.

Against the backdrop of medieval urban forestry in Europe (Brandl, 1973, Konijnendijk, 1997, 1999) the fate of the forests of Tallinn and its nearby islands in the Middle Ages was unparalleled and in many respects instructive, demonstrating the ability of the town to manage its for-

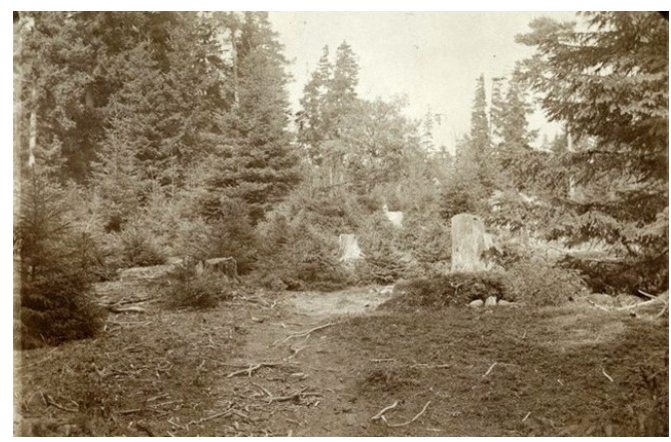

Figure 1. View of a spruce stand with high stumps on Naissaar Island in 1909.

Joonis 1. Vaade Naissaare saare kuusikule 1909. aastal, näha on kôrgelt saetud kännud.

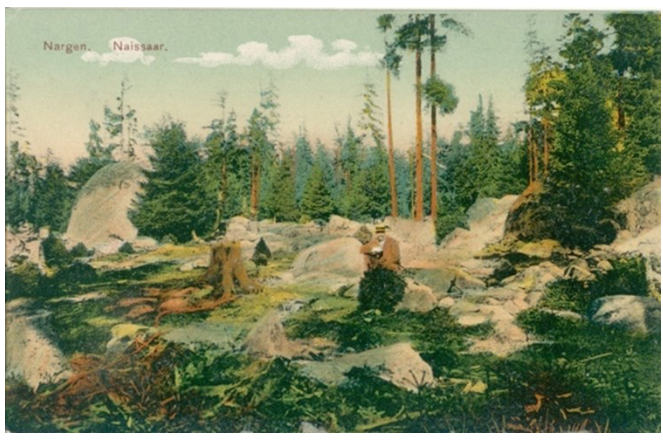

Figure 2. View of a clear-cut area with boulders on Naissaar Island before 1913.

Joonis 2. Vaade Naissaare raiesmikule koos rändrahnudega enne 1913. 
est fairly sparingly in an age of high timber consumption. Also instructive is the fact that if property relationships between the municipal and state authorities are not unequivocally determined from the very outset the state power will assert its rights, sooner or later.

\section{References}

Alamaa, E., Kivi, A. 1966. Tallinn. On the History of Settlements and Buildings in Seven Volumes. (Tallinn: Linna asustus ja ehitusajaloolisi materjale seitsmes köites). Vol.1-7. Tallinn, a manuscript in the Estonian Academic Library. $341,298,341,278,273,400$ pp and 223 pp. (In Estonian).

Brandl, H. 1973. Formation and management of the urban forest possession in the historical development, described by examples from southern Germany. (Entstehung und Bewirtschaftung von städtischem Waldbesitz in geschichtlicher Entwicklung, dargestellt an Beispielen aus dem süddeutschen Raum). - Allgemeine Forst- und Jagdzeitung, 144 (8), 154-162. (In German).

Daniel, O. 1927. Retrospect on the development of the character of the forestry in Estonia. (Rückblick auf die Entwicklung des Forstwesens in Eesti). - Tartu Ulikooli Metsaosakonna toimetised, 10, 73-138. (In German).

$\mathrm{DRB}=$ Blatt, F., Christensen, C.A. 1942. Letters of the Kingdom of Denmark. (Danmarks Riges Breve, Udgivet af det Danske Sprogog Litteraturselskab. 2. Række, 4. Bind). København, Munksgaard. 295 pp. (In Danish).

Gomercic, H., Bakic, J., Gomercic, V. 1997. Nature conservation in the laws of old coastal Croatian towns in the 13th century. - Proceedings of the conference "Nature Conservation in a Europe of Unification", Estonia, 11-13 September 1997. Tallinn/Naissaar. Estonian Ministry of Environment. 51-52.

Gustavson, H. 1992. About the history of Naissaar until the year 1940. (Naissaare ajaloost kuni 1940. aastani). - Vana Tallinn II (IV), 29-50. (In Estonian with German summary).

Gustavson, H. 1994. An overview of Naissaar. (Mõnda Naissaarest). Tallinn, Varrak. 62 pp. (In Estonian).

Hart, C.E. 1966. Royal Forest. A History of Dean`s Woods as Producers of Timber. Oxford, Clarendon Press. 367 pp.

Henricus, Kleis, R., Tarvel, E. 1982. Chronicle by Henry of Livonia. (Henriku Liivimaa kroonika $=$ Henrici Chronicon Livoniae). Tallinn, Eesti Raamat. 292 pp. (In Estonian and Latin).
Hørby, K. 1993. Denmark and Estonia in the Middle Ages. (Taani ja Eestimaa keskajal). - Nils, G.B., Tamla, T., Hørby, K., Riis, T. (eds.). 1219 Dannebrog and Estonia. (1219. Dannebrog ja Eestimaa). Roskilde, Denmark, Roskilde Muuseum, 30-38. (In Estonian).

Johansen, P. 1951. Northern mission. Establishment of Reval and Swedish Settlement of Estonia. (Nordische Mission. Revals Gründung und die Schwedensiedlung in Estland). Stockholm, Wahlström \& Widstrand. 405 pp. (In German).

Johansen, P., von zur Mühlen, H. 1973. German and Non-German of Reval in the Middle Ages and the Early Modern Time. (Deutsch und Undeutsch im Mittelalterlichen und Frühneuzeitlichen Reval). Köln, Wien, Böhlau Verlag. 555 pp. (In German).

Kala, T. 1998. The Lübeck Law and Tallinn City. (Lübecki Õigus ja Tallinn). Tallinn, Ilo Print. 45 pp. (In Estonian).

Kenkmaa, R., Vilbaste, G. 1965. Fortifications and Green Areas of Tallinn. (Tallinna bastionid ja haljasalad). Tallinn, Eesti Raamat. 87 pp. (In Estonian).

Kivi, A. 1937. From the borders of town land tenures and their protection, especially in Tallinn. (Saraste piiridest ning nende kaitsest, eriti Tallinnas). - Vana Tallinn, 2, 17-36. (In Estonian).

Kivi, A. 1959. The town land tenure of Tallinn, its borders and their protection. (Tallinna linna saras, selle piirid ja nende kaitse). Tallinn, a manuscript in the Tallinn University Academic Library. 87 pp. (In Estonian).

Kivi, A. 1975. Ferrying of beams and firewood in Middle Ages from Naissaar, Aegna and Kolga. (Palkide ja küttepuude parvetamine keskajal: Naissaarelt, Aegnalt ja Kolgalt). Tallinn, a manuscript in the Tallinn University Academic Library 7 pp. (In Estonian).

Konijnendijk C. C. 1997. Urban forestry: overwiew and analysis of European urban forest policies. Part 1: Conceptual framework and European urban forestry history. - EFI Working Paper 12. Joensuu, European Forest Institute. 130 pp.

Konijnendijk, C.C. 1999. Urban forestry in Europe: a comparative study of concepts, policies and planning for forest conservation, management and development in and around major European cities. - Academic dissertation. Joensuu, University of Joensuu, Faculty of Forestry. 182 pp.

LUB = Bunge, F.G. 1853. Livonian, Estonian and Courland Documents. First Volume (1093-1300). (Liv-, Esth- und Curländisches Urkundenbuch. Erste Band (1093-1300)) Reval, Kluge \& Ströhm. 188 pp. (In German).

LUB = Bunge, F.G. 1855. Livonian, Estonian and Courland Documents. Second Volume (1301-1367). (Liv-, Esth- und Curländisches Urkundenbuch. Zweite Band (1301-1367)). Reval, Kluge \& Ströhm. 830 pp. (In German). 
LUB = Bunge, F.G. 1857. Livonian, Estonian and Courland Documents. Third Volume (1368-1393). (Liv-, Esth- und Curländisches Urkundenbuch. Dritte Band (1368-1393)). Reval, in Commission bei Kluge und Ströhm. Druck von Heinr. Laakmann in Dorpat. Reval, Kluge \& Ströhm. 202 pp. (In German).

Meikar, T. 1998. The forest of Naissaar and man. - Talvi, T. (ed.). Nature Conservation in a Europe of Unification. Kuressaare, Publication of the West-Estonian Archipelago Biosphere Reserve, 225-239.

Meikar, T., Sander, H. 1999. Forest of Naissaar. (Naissaare mets). - Martin, J., Pärn, H. (eds.). Naissaare loodus ja selle kaitse. Eesti Vabariigi Keskkonnaministeerium, TPÜ Rahvusvaheline Keskkonnabioloogia Keskus, Euroülikool. Tallinn, Euroülikool, 28-42. (In Estonian).

Nottbeck, E. 1884. The old Real Estate of Reval. (Der alte Immobilienbesitz Revals). Reval, In Commission bei Emil Prahm. 86 pp. (In German).

Peep, V. 1995. A glimpse of the development of rights and court of Estonia. (Pilguheit Eesti õiguse ja kohtu arengule). - Kleio. Ajalooline ajakiri, 1(11), 16-26. (In Estonian).

Pullat, R. 1976. The History of Tallinn Until the Year 1860. (Tallinna ajalugu 1860-ndate aastateni). Tallinn, Eesti Raamat. 430 pp. (In Estonian).

Punning, J.-M., Koff, T., Ratas, U., Tann, R. 1998. Shoreline displacement and Vegetation history on Island Naissaar, Baltic Sea. - Journal of Coastal Research 14, 933-938.

Profous, G., Rowntree, R. 1993. Structure and management of the urban forest in Prague. Unasylva (FAO), 44(173), 33-38.

Riis, T. 1985. Administration of Estonia in Danish Time. (Die Administration Estlands zur Dänenzeit). - Nowak, Z.H. (ed.). Die Rolle der Ritterorden in der Mittelalterlichen Kultur. Ordines Militares: Colloquia Torunensia Historica. Toruń, Uniwersytet Mikołaja Kopernika. 117-127. (In German).

Roudna, M., Urban, F. 1998. History of nature conservation in the Czech Republic. - Talvi, T. (ed.). Nature conservation in a Europe of Unification. Kuressaare, Publication of the West-Estonian Archipelago Biosphere Reserve, 63-67.

Sander, H. 1997. A Brief Overview of the 700-Years' History of the Forest on the Island of Naissaar near Tallinn. (Lühiülevaade Naissaare metsade 700 aastasest ajaloost). - Proceedings of the Academic Forest Society. Part VII]. Tartu, 55 pp. (In Estonian with English summary).
Sander, H., Meikar, T. 1997. The forests of Naissaar from the 13th to the 19th century. -Sander, H. (ed.). - A Brief Overview of the 700-Years' History of the Island of Naissaar near Tallinn. - Proceedings of the Academic Forest Society. Part VII. Tartu, 15-25. (In Estonian with English summary).

Sander, H., Meikar, T. 2000. The significance of the law of King Erik VI Menved of Denmark from 1297 to the forests of the nearby islands of Reval/Tallinn (Estonia). (Die Bedeutung des Gesetses von König Erik VI Menved von Dänemark aus dem Jahre 1297 für die Wälder der Nahegelegenen Inseln vor Reval/ Tallinn (Estland)). - Archiv für Naturschutz und Landschaftsforschung, 39, 253-265. (In German).

Sander, H., Meikar, T. 2020. About the history of conflicts over urban forestry in Estonian towns. - Forestry Studies / Metsanduslikud Uurimused, 73, 1-25.

Tiik, L. 1957. About Medieval Sea Traffic on the Baltic sea and on the Gulf of Finland. (Keskaegsest mereliiklusest Balti merel ja Soome lahel). Tallinn, Eesti Geograafia Seltsi Aastaraamat. 207-230. (In Estonian with German summary).

Tiismann, B. 1931. State Power and Private Forestry. (Riigivõim ja erametsamajandus). Tartu, Eesti Metsanduse Aastaraamat. V, 3357. (In Estonian with German summary).

Truus, L., Ratas, U. 1995. The island of Naissaar in the past and present. (Naissaar, nagu ta oli ja on). - Eesti Loodus, 9, 241-245. (In Estonian with English summary).

Viidas, A. 1992. History of Viimsi: The Prehistoric Time and Middle Ages. (Viimsi Ajalugu: Esi- ja Keskaeg). Tallinn, Varrak. 109 pp. (In Estonian).

Vilberg, G. 1932. The forest state and quarrels in Estonia of the Order time. (Metsaolud ja metsatülid Eestis ordu-ajal). Tartu, Eesti Metsanduse Aastaraamat. VI, 9-38. (In Estonian with German summary).

Von Transehe-Roseneck, A. 1935. Genealogical Handbook of the Baltic Knighthood. (Genealogisches Handbuch der Baltischen Ritterschaften: Teil: Livland. Bd. 2, Lfg. 9.) Görlitz, Verlag für Sippenforschung und Wappenkunde C. A. Starke. 1218 pp. (In German).

Zobel, R. 1991. Historical territory of the city and land of Tallinn. (Tallinna ajaloolisest sarasest). Tallinn, Tallinn Art University, Architectural Series 1, 26-34. (In Estonian with English summary).

Zobel, R. 1994. The fortifications of Tallinn. Tallinn, Kunst. 58 pp.

Archive sources

TCA (Tallinn City Archives). F. 230, No. 10, s. 37.

TCA (Tallinn City Archives). F. 195, No. 1, s. 124. 


\section{Naissaare mets aastail 1297-1698 Tallinna linna käekäigu taustal}

\section{Heldur Sander ja Toivo Meikar}

\section{Kokkuvõte}

Siinses artiklis käsitletakse Tallinna (Põhja -Eesti) linna arengut ning Tallinna neljast lähisaarest suurima, Naissaare metsade ajalugu 13.-17. sajandil. 1219. aastal hõlmas Põhja-Eesti Taani kuningas Valdemar II, kes ehitas Toompea kõrgendikule kivikindlustuse. Põhja-Eestist sai Taani kuninga suveräänse võimu all Eesti hertsogkond, kus keskus ja ametkond paiknesid Toompeal. Kivilinnus arenes hiljem Toompea ja Vanalinna asulaks, esimene sai kuberneri ja riigivõimu residentsiks, teine kujunes välja kõrgendikku ümbritseval alal. 1248. aastal sai Tallinn Lübecki linnaõigused. Taani kuninga Erik VI Menvedi 1297. aasta seadus andis saarte metsade ühiskasutuse Tallinna linnale ja Toompeale (st riigile). Valdavalt mändidega, väiksemal määral kuuskedega kaetud Naissaare kõrgete puudega mets oli ka meremärk. 1297. aasta seadust on hakatud käsitlema kui looduskaitse algust Eestis, sest see oli esimene metsakasutust ja kasutajate ringi reguleeriv seadus. Kuna riik ei sekkunud linna asjadesse, pidas viimane ennast Naissaare ainuomanikuks. Järgneva nelja sajandi jooksul saigi Tallinn kasutada Naissaare (ka teiste lähissaarte) metsi, mille puitu kasutati väga mitmesugusel otsatarbel. Linn oli metsamajandamisel suhteliselt ökonoomne. Kuid esines ka konflikte, nii taotles Eestimaa kuberner 1642. aastal raelt dokumentaalset kinnitust
Naissaare kuuluvust linnale. Küsimuse lahendamiseks moodustati komisjon, kes ei suutnud lahendit pakkuda. Seda kasutas ära Eestimaa kuberner, kes 1645. aastal lasi hankida Naissaarelt rohkesti puitu, mis põhjustas linna pahameele. Seetõttu pidi sekkuma Rootsi kuninganna (1632-1654) Kristiina, kes 1653. aasta resolutsiooniga astus saarte metsade kuritarvitamise vas$\mathrm{tu}$, toetades metsade kaitsmisel Tallinna linna. Kubermangu valitsus, tundes oma kaasaomandi õigust saartele, hakkas Naissaare metsi rohkem kasutama, eelkõige fortifikatsioonitöödeks. See põhjustas linnas proteste ja vastumeetmeid, nii saatis raad 1686. aastal Naissaarele spetsiaalse vahtkonna, kes pidi jälgima, et rae tarbeks varutava ehituspuidu raiumisega ei mindaks liiale. Kui Rootsi riik viis 1689. aastal läbi mõisate reduktsiooni, siis riigistati peaaegu kogu linnasaras saartega. Kui muus osas sai linn oma endisi valdusi edasi kasutada, siis saared võeti riigi valitseda ja linnal keelati igasugune majanduslik tegevus, sealhulgas ka puude raie. 17. sajandi lõpul ja 18. sajandi algul nõudsid mitmesugused linnarajatised rohkesti puitu ja seda tarbiti ka Naissaarelt. Aastast 1700 on pärit Naissaare metsade kaart, kust nähtub, et suurema osa metsadest moodustas noor männimets loodusliku uuendusega, puudus aga korralik palgimets. 